\title{
特集【論説】 規制とルールによる景観形成の意義と課題
}

\section{新しい町並み景観のためのルールづくりに果たす自治体の役割}

The Role of Local Administration for Townscape Consensus Achieving

Yoshifumi MUNETA : Kyoto Prefectural University

宗田 好史*

\section{1. 景観づくりの合意形成に求められる二 つの説明}

2004年の景観法, 2008年の歴史まちづくり法に よって, 多くの自治体で景観政策への取組みが進 められている。しかし, 景観は新しい取組みでは ない。従来から景観に配慮した都市計画はあり， 都市デザイン，町並み保存，民間住宅地開発など， 個々の取組みの蓄積は大きい。また, 一部の自治 体にはすでに成果があり，また一部の自治体では 取組んだものの, 効果が不十分, そして大部分の 自治体では着手もされていなかった。

明治時代に官営で進められた銀座棟瓦街や中央 官衙街, 民間が進めた三菱棟瓦街, 近年でも横浜 MM21, 六本木ヒルズなどの市街地建設では都市 景観形成に成果があった。同様に，公団や民間に よる大規模な住宅市街地の開発でも, 計画的な景 観形成がなされた。これらは, 地権者の合意や市 民への説明責任が求められることはほとんどな かった。一方，1970年代に始まった町並み保存で は全国各地で, 住民の合意形成をへて, 伝統的建 造物群保存地区が生まれた。その他, 建築協定, 地区計画, 景観協定などの形で住民の合意形成に よって，歴史的景観を守る取組みが進んだ。こう して, 景観に優れた市街地は全国至る所に存在し, 多くの国民が日常の買物や観光で親しんでいる人 気ある街となっている。
景観法の特色は，この取組みを全国的に広げる 点にある。とはいうものの, 一般国民は優れた景 観の魅力を知っているが, 自分の街で具体的にど う取組まれるべきかを知らない。大部分の自治体 も, その取組み方法をよく知らず，まして市民に どのように説明したらいいかがわからない。その ために，景観政策に対するアカウンタビリティ不 足や合成形成の難しさが話題になっている。守る べき町並みがない自治体では特に難しいと思われ ている。

説明すべき点とは，まず優れた景観には様々な 利点があり，市民にはそれを享受する権利がある 点である。そして, 建築など土地利用が集合して 醸し出す景観というコレクティブな成果をえるた めには, 関係者相互が一定のルールの下に取組む 必要があるという点である。しかし，景観が不動 産価值として明確に示されているわけでなく, ま た，上から命令されず自主的にコレクティブな取 組みができるほどに民主主義に慣れていない一般 市民には, 景観の利点も地域ルールも説明しにく い。したがって, 景観まちづくりの現場では, こ れら 2 点をいかに分かりやすく説明するかが専門 家に求められる。

\section{2. 景観利益の捉え方について}

一般の市民も，優れた景観に不動産価値がある ことは知っている。どの町にも高級住宅地と呼ば 
れる一帯があり，所得階層の高い人が住んでいる。 その地価がなぜ高いかは, 目で見て分かることで ある。まず, 1 戸の敷地面積が広く, 住宅の建築単 価 (総建築費 $\left./ \mathrm{m}^{2}\right)$ が高そうである。一般にその 二つを負担できる人が住んでいる。同時に, 町並 み景観が優れていることも眼に入る。自然環境に 恵まれ, 海か山の眺望に優れ, 緑比率が高い。多 くの場合, その周辺には風致地区があり, 景観計 画区域が設けられている。

そこに住む人に話を聞けば, 高級住宅地には住 民・地権者の自主的なルールと都市計画上の規制 があり，それが不可欠であることも理解できる。 民間の広告物，公設掲出物など街路に面したもの だけでなく, 敷地内の生垣や植木の刚込みに至る まで，あらゆる眼につくものは地域住民の関心の まとで，隣人から注意されることが多いことを知 る。京都でも下鴨などの高級住宅地や, 都心の町 家街区の一部では, 洗濯物を街路から見える場所 に干すと，今でも近隣住民から注意されるがある。

しかし, どの町でも高級住宅地はごく一部であ り, 市民は一般市街地では自主ルールと都市計画 規制で，景観が改善し，地価が上がるとは思わな い。よくなった事例も知らない。高級住宅地の景 観はお金持ちだけの贅沢で，自分には手が届かな いと思う。そこに移り住むことはできても, 自分 の住む町をよくしょうとは思わない。ここに最大 の問題がある。

それは，これまで建築着工数があまりに多く， 景観が急速に変わったためでもある。道路や河川 などの公共事業も多かった。住民誰もが懐かしむ ほどの優れた自然景観があった所でも，自主ルー ルも法的規制もない無計画状態が長期間にわたっ て景観を壊してきたために, 諦めざるえない状況 に置かれていた。それほど急速な都市開発が進ん だのである。

そんな住民でも敏感に反応した事件もあった。 緑地が減る, 道路や大型店の建設など生活環境が
脅された場合である。暴力団や風俗店, 放置自転 車への反発も強い。高層マンションも同様に嫌わ れた。逆に, 学校など公共施設の転出・廃止, 店 舗の閉店などで, 生活利便性が損なわれたことに も反発が起こった。今後の人口減少社会では頻発 しそうである。

こうして，住民は今まで諦めていた点にも自覚 を持ち始める。自らの生活環境にとって何が好都 合で不都合であるかを知り，それを制御しょうと， 住民の自主的な取組みが始まる。取組む過程で, 行政に頼るだけで解決しない問題の多さに気付く。 自治体の都市計画行政権限は限られおり, 問題の 多くが民と民の問題として解決せざるえないこと を知る。しかし，自主ルールをつくる障害は，民 と民との合意形成の難しさにある。既存のルール を受入れ, 受入れさせるのは簡単でも, 新たにルー ルを作ることは難しい。第三者である行政は, 従 来の合意を尊重するが, 新たな合意形成は苦手と することも分かってくる。

一方，土地区画整理や市街地再開発事業のよう に利害が明確で, 権利調整手法があれば議論は進 みやすい。しかし, 一般のルールづくりの困難さ は, 景観を含む生活環境の利益が, 関係者にどう 及ぶかを知らず，また知っていてもその調整の方 法が分からない点にある。だから，まちづくり憲 章のような紳士協定にまとめることが多い。紳士 協定には限界がある。実際の町では理不尽な不公 平もまかり通っている。資産価值が損なわれ，生 活に関わる様々な権利が侵害されたと感じる市民 は至る所にいる。そのために訴訟を起こし, 裁判 所の判断を仰ぐ人も多い。しかし, 資産価值から 景観問題を提起した訴訟も判例もまだ少ない。だ から, 一般市民の日常では景観の利益は認識され ることが少ない。

反面, 生活環境に関わる要素の中でも日照や騒 音については, 明確な補償の基準が整っている。 また, 建て混んだ都心商業地では, 法的な根拠が 
なくとも，昔から地権者間で一定の調整をした経 験もある。人口も経済も低成長に転じる近い将来, 建築着工数が減り, 限られた都市空間の効率的な 利用に関する市民・事業者の関心が高まれば，景 観に関する争点も増えてくるだろう。西欧先進国 では1970年代以降, 人口と経済が低成長に転じた ため, 郊外開発が抑制され, 既成市街地の再編が 進んだ。今後, わが国も同様の道をたどり，権利 調整の手法が発達するだろう。地価の上昇傾向が 止まり，上る所下る所が分れてきた。生活利便性 に加えて, 景観を含む優れた環境を欠く住宅地は 衰退し始めている。

実際, 近年の地価の変動要因を解析してみると, 容積率など開発可能性に関わる要素, 駅・都心へ のアクセスなど需要に関わる要素は寄与する割合 がまだ高いものの, 住居系市街地では, 個々の敷 地面積, 緑比率などの寄与率が高く, 景観が地価 の安定に関わることも知られる。今後より詳細な 研究が待たれる。また, 現実の住宅市場も変化し ている。

わが国でも住宅設備の改善が一段落し, 住宅更 新は沈静化しつつある。国の住宅政策もストック 重視, 長寿命化の方向に転換した。京都では町家 の評価が高まり, 築100年近い優れた町家が 1 億円 以上で売買され, 多額の改修費用を惜しまずに再 生する例が増えている。老朽化した設備の一部を 更新するだけで，高級材をふんだんに使った近代 和風住宅が手に入る。同品質の材料を使用した新 築よりも安上がりで, 昔の職人の技術は現代では えがたいものでもある。同時に, その町家周辺に 景観規制がかかっていれば，その価值は一層確か なものになる。将来, 価值が上がる町に立派な町 家をもつことは，鑑識眼があれば上手な投資でも ある。しかし, 鑑識眼をもつ不動産業者も, 取引 額もまだ極めて少なく, 西欧諸国のように歴史的 建造物や景観への不動産評価は十分に定まってい ない。だから，文化的な側面から価值を訴えるこ
とが多く，利害調整が検討されることも少ない。

\section{3. 規制や地域ルールによる景観まちづく りの課題}

優れた景観には, 眺望や緑地, 河川など個々の 要素が貢献している場合, またマンションや大規 模開発など一つの開発事業が壊す場合など, 個々 の要素が特定できるものがある。また，町並みの ように個々の建物が多数集まって群として景観を 形成している場合がある。個々の要素の場合はそ の影響が分かりやすく, 守るにせよ阻止するにせ よ, 関係者の合意は比較的えやすい。だから保存 運動も反対運動も直ぐ活動できる。しかし, 集団 の場合は, 個々の建物や工作物, 広告物が景観全 体に与える影響が小さく見え, 関係する人々の理 解もまちまちである。多くの市民は自宅の形態が 景観にどう関わるか意識することは少ない。

また, 景観法の景観重要建造物ができるはるか 以前から, 景観に重要な影響を与える歴史的建造 物や樹木, 街角の老舗や社などは各地に存在して いた。しかし，大部分の市民はその価值を語るこ となく, その貢献度を讃えず, 失われて初めて気 づく程度であった。

さらに，わが国の建築教育では，単体の建築意 匠は教えても, 集団の建築形態・意匠, 町並みづ くりの計画手法は教えない。だから, 設計者の多 くは隣接する周囲の建物の意匠を考慮せずに, 単 体の形態や色彩を決めてしまう。専門家がその程 度なのだから, 素人の建築主は意識することがさ らに少ない。例えば, 外壁の色一つとっても, 色 見本と単価表から選ぶだけで, 隣接する建物との 色合わせはあまり考えない。アメリカ人やドイツ 人と違い, フランス人, イタリア人並みにファッ ションに煩い日本人が, どうして建物の形態や色 彩に無頓着なのか不思議だと言われる。ネクタイ とワイシャツ, スーツと靴の色合わせができて, なぜ町並みではできないのか。町並み景観への期 
待が薄いのだろう。あるいは奇抜なファッション を好む一部の若者のように, 揃わないことで個性 をアピールしたいのか。だが，それが美しく目立 てばいい。しかし，そうでない場合があまりに多 い。

この程度の意識で, 景観のルールを作ろうとす るのだから難しい。屋根は平入りで, 色彩は褐色 と白でなどと決めることもできない。揃えるとか コーディネートするという集団規定とその価值に 気づくことから始めなければならない。町並み保 存は30年以上続いたが, 多くの人々は古いから残 すのだと思っている。町並みは, 形態と色彩が揃っ ているから美しい。新しく造った町よりも美しい から人が集まり，住みたくなるから残すのである。 だから，逆に揃っていれば新しくても美しくなる のだが，その点に気付く人は少ない。

結局, 専門家がガイドラインを作ることになる。 それが示されれば, なぜこの色, なぜこの形なの か次々と疑問と反論を呈してくる。揃えて美しく なる価值を理解しないのだから, 京都でも市民に 分かりやすくするために「京都らしさ」をデザイ ン基準の根拠にした。しかし, 京都らしさなど技 術的には示せない。デザイン基準の内容は, 周辺 に馴染む色と形であり，それが町並みを揃える方 法であることを示しただけなのである。

本来, 美しい町並み景観をつくる原理は複雑で はない。各地で, 建物の高さ, 屋根・庇, 外壁の 形態, 材質, 色彩, さらに建築線を揃え, 生垣 ・ 石垣・塀などを示したガイドラインができている。 各国でもその程度のものが多い。京都市の新デザ イン基準も, 同程度のものである。そして, その 内容は従来から行われていた基準を拡大・充実し たものに過ぎない。1200年間に京都に建った無数 の建物を分析したわけでも, 天才的な建築家に委 ねたものでもない。現に, 市内に数多く存在し, 多くの市民が好ましいと思う最大公約数的な建築 をもとに，揃いやすい姿を示しただけである。実
際, ある文化人類学者の調査でも, 他都市と違っ て京都市民には町家に代表される都市的な和風建 築を好む傾向が示された。一般に, 瓦屋根と黒褐 色と白壁の建物が好まれる。だから，揃いやすい 基準なのである。

それでも理解しない少数の市民がいる。返って 「京都らしさ」という表現が混乱を呼んだ面もある。 単体で京都らしさを出すのでなく, 集団で京都ら しさを創ろうという発想も説明もない。さらに向 三軒両隣が揃うことで町並みが整うという, 半世 紀前まで長年続いていた市民共有の常識が失われ たことも大きな理由である。旧市街地には，デザ イン基準以前から，一定のルールで町並みが揃っ ている地区は多い。江戸時代の町定に, 家の意匠 は両隣と揃える旨が記載され，1950年代に非木造 が増えるまではよく守られていた。それを復興し て, 高札にした町もある。町内で, これまでに町 並みづくりに取組んだ住民には，デザイン基準は よく理解された。自分たちだけでは難しかった ルールづくりの具体例を市役所が率先して示した ことで，住民の理解が一気に進んだのである。

幸い京都市では，市民の町家再生への関心は高 く, 新景観政策についても, 京都新聞のアンケー 卜調査で市民の $80 \%$ が支持しているとの結果が出 た。市議会も全会一致で関連条例の制定と改正を 決めた。今のところ, 一部の設計者や工務店から 市役所の空口業務への不満が出ているものの, 町 家街区での調和あるデザイン基準は十分に受入れ られている。しかし, 問題は, その周辺と郊外住 宅地にある。揃えるべき基準の根拠が見えにくい のである。しかし，京都市の新しい景観政策では， 新市街地の大半にもデザイン基準を定めた。

新市街地の大半では, そこが風致地区や三山の 山麓や寺社の周囲であっても, 今まではパステル カラーの没個性的な建売住宅が許されてきた。初 めて家を買う消費者は, 周囲の景観よりも建物単 体のデザインで選んできた。売りやすさを重視す 
る建売業者と住宅メーカーは, 景観への配慮を欠 いていた。地中海に憧れて, 海のない京都で漆喰 壁紛いのべニアを張った安普請の家がいいと煽ら れるのである。購入するのは40歳前後の夫婦が多 く, 家の選択は主に妻がするから, 売りやすい新 築住宅の意匠は偏ってしまう。まして, 町並みを 揃える基準となる風趣ある景観もない。だから， その人たちにも分かるように, デザイン基準の必 要性を説明することは難しい。設計次第でどのよ うにも工夫できるのだが，その手間を惜しむ業者 から, 基準のため部屋が小さくなった, 天井が低 くなったと言われれば，デザイン基準を恨むこと になる。示された基準を尊重しても, その効果も 見えにくい。だから, 京都の例からも分かるよう に，一般の市街地で町並みを揃えるためには，集 団としての景観を形成するために必要な基準と ルールを市民に分かりやすく説明する必要がある。 揃った町並みの美しさを示すことできれば，一定 の理解はえられるだろう。

\section{4. 景観という新しい都市計画手法}

しかし，それ以上に重要なことは, 全建築着工 数の 9 割を占める住宅の意匠を決めているのは, 住民ではない点にある。現在, 都市部で大規模に 住宅を供給しているのは, マンション開発業者と 建売業者である。一般市民は, すでに建てられて いる住宅を買うだけである。建物や町並みの意匠 を自分で決めることは少ない。自宅を建替える場 合でも，住宅メーカーの製品を買うことが多い。 賃貸住宅に住む人は, 当然ながら建物意匠を決め る立場にはない。大家ですらプレハブのアパート を選ぶ場合が多い。だから，建物の意匠・デザイ ンを通じて景観形成に関わる市民は意外に少ない ことが分る。むしろ, 極一部の関係者が, 市民全 員に関わる街の公共財である景観に強い影響を与 えている。

売りやすい住宅を供給しがちな開発業者が, バ
ラバラに自らの利益を追求すると全体の利益を損 なう場合がある。その町に本来に備わっていた景 観の価值を阻害, あるいは独占することで, 都市 全体の不動産価値を下げる場合である。京都の場 合でも, 町家街区に高層マンションを建てる業者 は, 広告に町家を載せる。しかし, 町家に揃えた 中低層の集合住宅なら別だが，11階のその高層マ ンションが建てば，その魅力である町家と町並み が損なわれる。だから自治体の役割が重要になる。 競争原理の限界を乗りこえるために, 合理的で計 画的な規制が求められ，そのルールを尊重しつつ 開発を進めるから市民・消費者が賢く判断できる 真の市場原理が働く。市場にはルールが要る。都 市計画本来の役割である。

これまでも都市計画は, 都市施設と土地利用の 合理的な配置を示し, 効率的に社会経済を発展さ せ, 公共の福祉の増進に努めてきた。開発業者に 合理的な道筋を示すことで行政と民間の役割分担 を果たしてきた。急速に市街地を拡大させ, 遅れ た社会基盤整備を急ぐ必要が少ない現在, コンパ クトでより美しい都市・国土空間を整備するため の合理的な規制がデザイン基準である。2003年の 「都市再生ビジョン」に示された, 集約・修復保存 型都市構造へ転換し, 良好な景観と地域文化に恵 まれた都市美空間を創造するためにより詳細に建 築を規制する, 都市計画の手法としてのデザイン 基準が必要なのである。

集団規定としての町並みづくりのデザイン基準 への理解がえられにくいために，建物単体の景観 を評価しようとし, 単体に及ぶ規制だけを取り出 して，デザイン基準の是非を論ずる場合が多い。 その理由は，これまで政治的ではあっても不毛な 景観論争に終始し, 美しい景観をどう創るかを具 体的に考えなかったからである。また, 地域ルー ルをつくり景観まちづくりに取組んだ経験にもそ しいからである。だから, 規制緩和の時代に, な ぜ規制を強化するのかと筋違いな意義が唱えられ， 
またこの規制が，社会経済の合理的な発展を目的 とすることも理解されない。まして, 都市活性化 といえば，観光客のために市民に我慢を強いるの かという反論が出てくる。

また，京都のように歴史的で美しい町並みを持 たない全国の普通の街では，景観規制への理解は さらに難しいだろう。しかし, 機が熟すれば市場
の方が早く反応するだろう。EU諸国の多くの都 市がすでに経験したように，美しい景観の価值は 市民・消費者が評価する。美しさを欠く街は選ば れない。わが国の人口が 1 億人を割る 2050 年に, 新たに住み，投資をするだけの価值ある地方都市 は少ないだろう。早く気づいた町だけが選択され よう。 